\title{
Towards an Improved Bio-Resource Management System
}

\author{
Pallab Paul ${ }^{1 *}$ and Indeesh Mukhopadhyay ${ }^{2}$ \\ ${ }^{1}$ Professor of Marketing, University of Denver, USA \\ ${ }^{2}$ Cornell University, USA
}

Submission: October 30, 2019; Published: November 05, 2019

"Corresponding author: Pallab Paul, Ph.D., Professor of Marketing, Daniels College of Business, University of Denver, 2101 S. University Blvd, Room 497, Denver, CO 80208, USA

\section{Abstract}

Bio-resource management is a burning issue today - a debate that ranges from private to public use, from economic perspectives to ethical issues, and from basic necessities to luxury consumptions. One issue that everyone agrees on is that it in crisis mode and something must be done. Based on the recent technological advances, this paper offers multiple forms of solutions to a better bio-resource management system.

Keywords: Bio-Resource; Management System; Physical Environment

\section{Opinion}

Bio-resource management is an issue that concerns sustainability of the global commons that humans depend on. This sustainability is sought to be ensured through reduction of environmental stressors that are generated through unplanned, unintended activities of humankind. Earth's interlocked web of life is stressed through degradation in biotic (living environment including all organisms) and pollution in abiotic (physical environment like space, temperature, soil, air and precipitation) factors. These factors are involved in the production and consumption processes of energy and nutrient use in agriculture, industry and human services.

Generally, there is a constant tussle between private and public use of bio-resources. There is difference of opinions over primacy of utilitarian economic imperatives of 'wise-use' of the environment by the agri-business and industrial sectors and the political-ethical imperatives of sustainable conservation of the various green grassroots movements.

The economic perspectives tend to put a value on resources through cost-benefit analyses and generate market-incentive based solutions like green taxes for emissions and tradable permits. However, many people object to such an efficiency and risk analysis based on two grounds. First, the science of such evaluation is never conclusive. This is due to the inherent uncertainty involved in assessment of reality due to overdeterminative outcomes of interactions of natural and social factors; limited ability to garner comprehensive knowledge of every relevant factor due to specificity of the evolutionary stage of science; and multiple political, cultural and institutional barriers to knowledge gathering and analyses. Second, there is moral objection to putting monetary value on human life and all-natural resources that are necessary to its sustainability over generations. Green proponents, like the Sierra Club, the World Wildlife Fund, then prefer to have government regulation-based solutions that proactively take conservative measures and help create public awareness and restraint in behavior [1].

Despite the differences in power, interest and values, all relevant interest groups are increasingly concerned about the visible and hidden costs of environmental degradation. These include concern over the loss of ecosystem services provided by the natural environment, like clean water and air, biological diversity that ensures food and medicinal provisions, biological processes like nitrogen fixation, etc. These concerns emanate from economic concerns of diminishing returns as growth outstrips the carrying capacity or replenishment capacity of the environment as well as from ethical concerns of justice. Hence, there is a growing need to coordinate actions at the national and international level in order to ensure an economically and ecologically viable outcome based on contingent needs. In the following paragraphs we outline some of the critical drivers of bio-resource management imperatives, in order to point to the growing concern for the need for cooperative efforts [2]. 
Human activities have had serious impact on the environment. For example, in agriculture, land-overuse through overgrazing and intense cultivation has led to soil degradation through reduction in soil nutrients and aquifer depletion. Intensive use of chemical fertilizers and pesticides to increase productivity has contributed to contamination of groundwater, a critical source of drinking water. It has also contributed to global warming through carbon emissions.

Climate changes through global warming have contributed to melting of glaciers, rise in sea levels and breakdown of permafrosts that support significant areas of forestry. Due to these changes, weather patterns have changed. Imbalanced cycles of floods and droughts have emerged. This is due to decimation of forest covers through over-logging and the consequent impact on disruption in patterns of transpiration and precipitation. Lack of forest covers has caused significant soil erosion and desertification. This has been exacerbated by destruction of coastal wetlands that act as absorption sinks for storm waves. Such drastic changes have impacted agricultural yields and have contributed to increase in famines [3].

The creation of artificial barriers to control floods, like dams, on rivers and lakes has led to disturbance of wildlife habitats. This has occurred through reduction in forest covers and through creation of isolated islands of habitats instead of contiguous stretches of land needed to enhance biological range of survival of species. This has led to the reduction in species richness.

Overfishing or excessive commercial harvests has resulted in depletion of natural reserves in freshwater streams and oceans. Illegal commercial hunting or poaching has also contributed to extinction of large animals. Overall imbalance in the eco-system has led to introduction of invasive species and destruction of natural eco-web of life of predator-prey relations. Generally, one can observe increasing development of genetic abnormalities among various species (including humans) due to various environmental stresses [4].

Besides agriculture, increased urbanization of coastal areas and the interior has led to deforestation, destruction of wetlands and extinction of land and aquatic species of various kinds. Extensive unplanned urbanization has also caused degradation in water quality due to increased burden of population, lack of proper sanitation facilities in slums and contamination of groundwater through leaking of untreated animal and human sewage.

On the industrial side, the extensive use of harmful chemicals in manufacturing has led to pollution of air through generation of greenhouse gases and thinning of the ozone layer. It also leads to pollution of land and destruction of forests through generation of acid rains. Similar to agricultural overuse, unsustainable mineral extraction through processes like surface mining has led to huge wastelands and increased acidity and salinity of soil and pollution of groundwater through leaching of chemicals into the ground.
Given the above-outlined problems, multiple forms of solutions to resource-management have emerged. Conservation-based pricing focuses on rewarding consumers for using less water. This can be very effective, especially in well-planned urban areas. This can engender private conservative-use of water through practices like recycling of grey water created from showers and dishwashers for using to flush toilets or irrigate gardens. Such irrigation could be enhanced through drip irrigation. Transboundary and interstate cooperation also help to ensure comprehensive and fair management of water resources [5].

Use of pesticides has sought to be reduced through a variety of ways. These include enhanced use of biological (predatorprey) and reproductive (sterilization) modes of pest control; integrated modes of pest management through use of a variety of forms of farming including cross-bred and genetically modified pest-resistant plants; use of advanced technology like the use of agricultural vacuums to eliminate pests; conservation tillage and crop rotation practices instead of monocropping; etc.

Farmers have sought to ensure continued soil fertility through use of organic fertilizers made from animal manure, crop residues, etc. and following innovative technologies emerging in green chemistry. They have also practiced agro-forestry - trees and crops planted together - to enhance soil fertility and reduce soil erosion.

Biodiversity has been sought to be maintained through creation of international germplasm banks that store genetically diverse crops and sperms of traditional livestock breeds. Commercial harvesting of aquatic resources has been sought to be regulated through increased focus on development of aquaculture [6].

Establishment of natural parks, preferably in the biodiversity hotspots of the world, can provide both conservation and recreation for people seeking solitude from the stress of urban life and aesthetic pleasure. Such natural parks can be forest land or marshlands. Forests can help provide watershed protection, sinks for absorption of carbon emissions, and provide for wildlife corridors to allow for increased breeding potential of species. Marshlands can help build up aquatic species reserve. In addition, ex situ conservation of biodiversity can be ensured through zoos.

Derelict lands decimated through mining can be restored through reclamation projects. This can be done through creation of topsoil covers and planting of trees that can absorb and accumulate toxic materials, like nickel, from the soil. It can also be done through creation of wetlands that breaks down all forms of pollutants. The use of biological products like cow manures also helps to increase the $\mathrm{pH}$ of the mine drainage water by encouraging the formation of bacteria that feeds on such waste and releases oxygen in the process. The enactment of greener mining practices like bio-mining that uses microorganisms to extract minerals from low grade ores can also be useful way to manage natural resources. 


\section{Annals of Social Sciences \& Management studies}

All such efforts, however, fall short when it comes to developing countries. These countries have the richest sources of biodiversity and minerals, but do not have the political will and financial resources to conduct effective bio-resource management. Hence, the development of international norms of corporate behavior about mining, hunting, fishing, etc. has been critical. Also, critical has been the establishment of financial, educational and research assistance through various international grants. This has helped developing countries make headway in dealing with environmental problems.

\section{References}

1. Butterfield JS, Bingham, A Savory (2006) Holistic Management Handbook: Healthy Land, Healthy Profits. Washington, DC: Island Press.
2. Raven PH, LR Berg, DM Hassenzahl (2008) Environment, NJ: John Wiley and Sons Inc.

3. Rockwood L, RE Stewart, T Dietz (2008) Foundations of Environmental Sustainability: The Coevolution of Science and Policy, NY: Oxford University Press.

4. Singh JS, A Kumar AN, Rai, DP Singh (2016) Cyanobacteria: A Precious Bio-resource in Agriculture, Ecosystem, and Environmental Sustainability. Frontiers in Microbiology 7:529.

5. Smajgl A, S Larson (2007) Sustainable Resource Use: Institutional Dynamics and Economics, London: Earthscan.

6. Thakur AK, R Maiti, C Nalwa (2018) Bio-Resource Conservation and Management Research in Trends in Bioresource Management and Technology, Eds, R Maiti, HG. Rodríguez, B Ghosh, NC Sarkar, D Mandal, R Meena, AK Thakur, AV Ramanjaneyulu, American Academic Press.

\begin{tabular}{l} 
Your next submission with Juniper Publishers \\
will reach you the below assets \\
- Quality Editorial service \\
- Swift Peer Review \\
- Reprints availability \\
- E-prints Service \\
- Manuscript Podcast for convenient understanding \\
- Global attainment for your research \\
- Manuscript accessibility in different formats \\
( Pdf, E-pub, Full Text, Audio) \\
- Unceasing customer service \\
Track the below URL for one-step submission \\
https://juniperpublishers.com/online-submission.php \\
\hline
\end{tabular}

